\title{
A bio- evaluation of the effects of anthropogenic activities around Oguta lake, south - east, Nigeria
}

\begin{abstract}
Oguta Lake serves for several beneficial human uses ranging from Agriculture, sand dredging, cassava fermentation, and washing. Despite these, the Lake receives anthropogenic inputs from the recent channeling of the community waste through erosion, which are capable of causing deteriorating effect on the biota and community at large. Thus the need to assess the likely effects of these wastes using the Macro-invertebratess assemblage to evaluate the habitat stability. Bi-monthly sampling of some physico- chemical parameters and Macroinvertebrates were carried out for three months. Temperature range between $27.00-29.50^{\circ} \mathrm{C}$, Ammonia range between $0.32-0.91 \mathrm{mg} / 1$ and Dissolved oxygen range between 4.60 $10.00 \mathrm{mg} / 1$. Chironomus $s p$ recorded the highest percentage abundance of $34.3 \%$, while Melanoides tuberculata, Sympetrum $s p$ and Atoperla $s p$ have the least abundance. Also, Chironomus $s p$ recorded the highest diversity index of 2.344 while Mayfly nymph recorded the least evenness of 0.818 . The study revealed that all the physico- chemical parameters measure were within the allowable limit for Aquaculture excepts $\mathrm{pH}(5.83 \pm 0.09)$, Ammonia $(0.63 \pm 0.04 \mathrm{mg} / \mathrm{L})$, and Total Suspended Solid $(3.84 \pm 0.51 \mathrm{mg} / \mathrm{L})$, while the recorded low mean diversity index in the Macro- invertebrates could be as a result of high suspended solid capable of lowering the dissolve oxygen and also cause destruction of the Macroinvertebrates habitat, thereby making the habitat unstable.
\end{abstract}

Keywords: physico-chemical parameters, macro-invertebratess, anthropogenic activities, Oguta Lake, Nigeria
Volume 3 Issue $6-2019$

\author{
Adebayo ET,' Ekeledo CB² \\ 'Department of Biological Sciences, University of Medical \\ Sciences, Nigeria \\ ${ }^{2}$ Department of Fisheries Technology, Federal Polytechnic \\ Nekede, Nigeria
}

\begin{abstract}
Correspondence: Adebayo ET, Department of Biological Sciences, University of Medical Sciences, Ondo City, Ondo State, Nigeria, Email Adebayotemitop.et@gmail.com, tadebay@unimed.edu.ng
\end{abstract}

Received: November 25, 2019 | Published: December 17, 2019

\section{Introduction}

The availability of good water is an indispensable feature for preventing disease and improving quality of life, however, Pollution of water ways by organic discharges in Nigeria is presumably a serious threat posed to the Nigerian inland waters. ${ }^{1}$ The notable point source arise from the dumping of untreated and partially treated sewage into the river, ${ }^{2}$ brewery effluents into the river, ${ }^{3}$ discharge of biodegradable wood waste from sawmill located along the river, ${ }^{4}$ which are introduced into aquatic ecosystem as direct discharge from industrial plants or as surface run-off from municipal and Agricultural fields. These wastes cause ecological degradation with the attendant severe adverse consequence on the aquatic biota. ${ }^{1}$ A short term exposure of benthic organism to water of poor quality causes an alteration in the community structure due to the elimination of sensitive species, hence the significant of bio-assessment as an evaluation of the condition of water body using biological surveys and other direct measurements of resistant biota in surface water., ${ }^{5,6}$ The concepts of assessment of Oguta Lake become ecological necessary due to the recent channeling of drainage canals in addition to increase irrigation farming along its bank. These can increase waste discharge into the lake which may likely have an adverse effect on the ecological stability of the lake. Though a lot of research have been done on its plankton species diversity, ${ }^{7}$ the origin and study area of Oguta Lake, ${ }^{8}$ heavy metals concentration in water and sediment, ${ }^{9}$ heavy metals in fish species and some physico-chemical parameters of Oguta Lake. ${ }^{10}$ But recently, few works is documented about its benthic Macro-invertebratess, thus the need for this research work in order to ascertain its purity level as well as the composition, abundance and distribution of Macroinvertebratess of the lake.

\section{Materials and methods}

\section{Description of the study}

Oguta Lake is situated in Oguta local government Area of Imo State; it constitutes the largest natural lake in Imo State, South East Nigeria. It is located between latitude $5^{\circ} 42^{\prime} 24^{\prime \prime} \mathrm{N}$ and longitude 6.4733 "E and has a maximum depth of $8 \mathrm{~m}$ and a mean depth of 5.5 and water surface area that varies from $1.8 \mathrm{~km}^{2}$ in dry season to $2.5 \mathrm{~km}^{2}$ at the peak of the rainy season. The length of the shoreline is approximately $10 \mathrm{~km} .{ }^{11}$ The region is located within the equatorial rain forest, with an average annual rainfall of $3,100 \mathrm{~mm}$. Oguta Lake increases in size during the rainy season when it receives overflow and floodwaters from its tributaries (Utu, Awbuna and Njaba River), although river Utu is seasonal, taking its source from river Orashi (an outlet of Oguta lake), and normally empties into Oguta during the high tide (Figure1). Oguta Lake drains into Orashi, a main river on the east- bank flood plain of the Niger and which conveys river Niger's flood waters directly into Niger delta.

\section{Sample Collection and Analysis}

Three (3) sampling stations based on anthropogenic activities around the Lake were selected for study. Bi-weekly samples were collected for the period of three months (July-September, 2019) between the hours of 08:00am-10:00am on sampling days. In-situ 
measurement of temperature, current, and transparency was carried out using mercuy-in-glass thermometer, floater, meter rule, stop watch, secchi disc according to. ${ }^{13}$ Surface water samples for chemical parameters were collected from all sampling stations in pre-sterilized $750 \mathrm{ml}$ plastic bottles and transported to the Department of Fisheries and Aquaculture Technology Laboratory, Federal University of Technology Owerri, for analysis.

Water samples for Dissolved Oxygen was collected and fixed immediately using Winkler's solution A and B as described by Mackereth. ${ }^{13}$ Likewise sediment sample for benthic Macroinvertebrates was collected using kick method and Eckman grab respectively. Two to three hauls of the sediment was collected using the grab and transferred into a pre-labeled polythene bag and transported to the Department of Fisheries and Aquaculture Technology laboratory, Federal University of Technology Owerri, for analysis. For kick method, the sediments was swept two to three times using a $1 \mathrm{~mm}$ mesh hand net and transferred in to a bucket half filled with water and transported to the same laboratory for Identification. Water samples for physic-chemical parameters were analysis using a standard method, ${ }^{14}$ while the sediments samples were washed through a $0.595 \mathrm{~mm}$ size sieve. The benthos was collected with forceps into the tray for further sorting, identification, counting and subsequent preservation with $10 \%$ formalin. Identification was done using identification guides of APHA/AWWA/WEF, ${ }^{15}$ and Hawkin. ${ }^{16}$

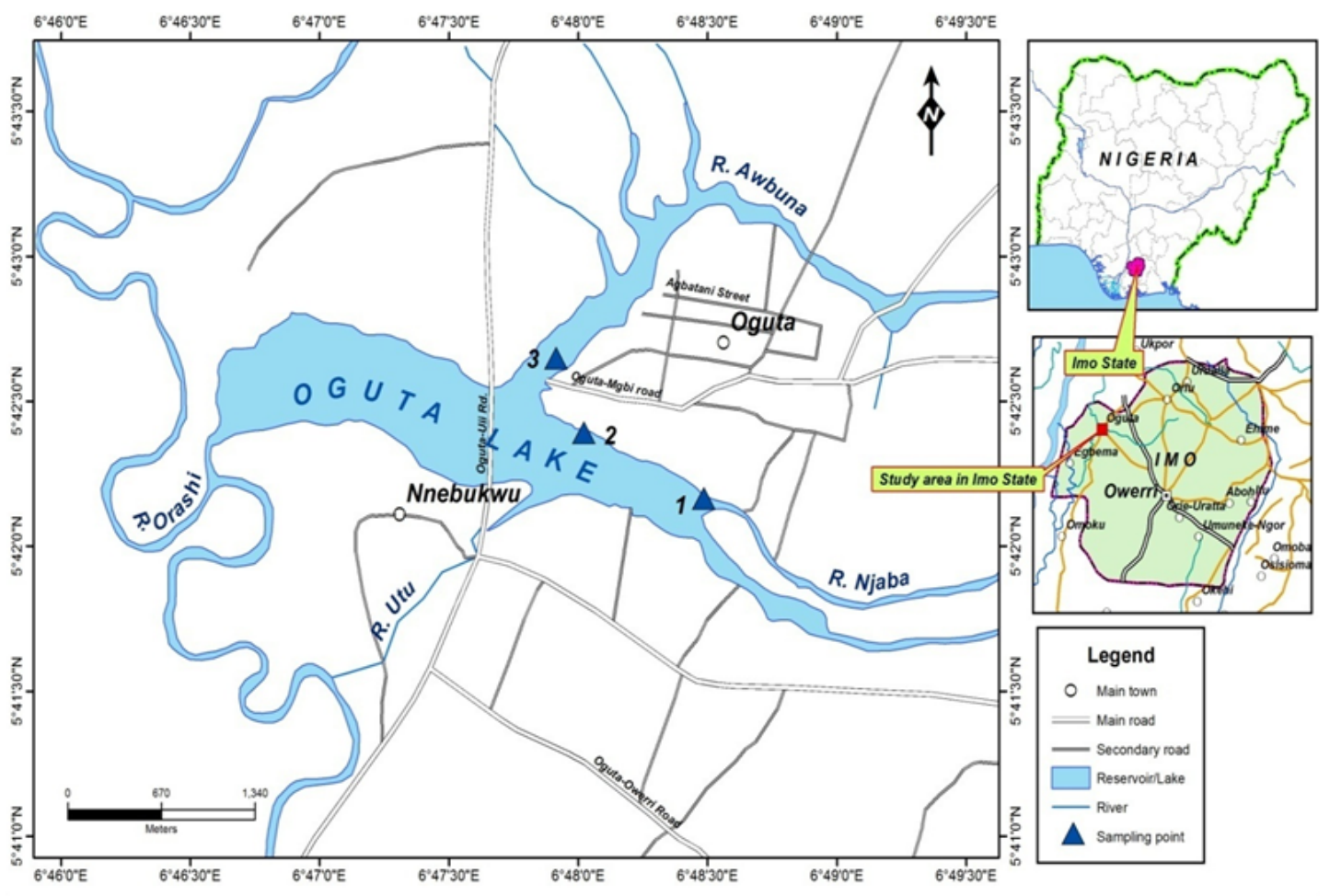

Figure I Map of Oguta Lake showing the sampling stations (Source: Cartographic unit, Department of Geography, University of Ibadan, Ibadan. February 20I9).

\section{Statistical analysis}

Descriptive statistics and Duncan's Multiple Range Test was used to separate the mean and to check the significant differences in each physico-chemical parameters. One way Analysis of variance (ANOVA) was used to compare the means of various parameters between months, when differences occur. Shannon- wiener $(\mathrm{H})$, Margelef index (D), and evennes (J) was used to determine the species distribution, measure species richness and even distribution of the benthic Macro-invertebratess. Significant level was taken as $\mathrm{P}<0.05$.

\section{Results}

\section{Physico-chemical parameters}

The results of the physico-chemical parameters of Oguta Lake in Oguta LGA of Imo State, Southeastern Nigeria measured across the sampling locations from July to September 2019 are shown in Tables $1 \& 2$, and Figures 2-6 respectively. The lake water was shown to be slightly acidic in nature. Also, the ammonia concentration of the lake was shown to exceed the recommended limits, while the suspended matters were observed to be on the extreme (Table 1). Ammonia concentrations and the dissolved oxygen were only recorded to vary across the sampling stations (Table 2).

\section{Macro-invertebrates fauna of Oguta Lake}

The checklist of the identified Macro-invertebrates fauna in Oguta Lake during the study period is presented in Table 3. A total of 137organismsfrom two classes (Gastropoda and Insecta) in two phyla (phylum Mollusca and Arthropoda) were recorded (Table 4) in the lake. Gastropoda had 2species, while Insecta was represented by 8 species. Class Insecta dominated the recorded Macro-invertebratess (Table 5) fauna, and constituted $97.8 \%$ of the total Macro-invertebratess populations, while Gastropoda was least abundant accounted for $2.2 \%$ of the entire population. The sensitive species was observed to recorded the highest abundance of sixty while tolerant specie had the least abundance of the encountered organism (Figure 7). 
Table I Descriptive statistics of the Physico-chemical Parameters of Oguta Lake between July and September, 20I9

\begin{tabular}{lllll}
\hline Parameters & Range (Min.-Max.) & Mean \pm SE & NESREA (20I I) & WHO (1998) \\
\hline Temperature $(\mathrm{OC})$ & $27.00-29.50$ & $28.00 \pm 0.20$ & $\mathrm{~A}$ & $30-32$ \\
Transparency $(\mathrm{m})$ & $0.40-2.25$ & $1.15 \pm 0.1 \mathrm{I}$ & $\mathrm{NS}$ & - \\
Current $(\mathrm{m} / \mathrm{s})$ & $4.03-24.14$ & $12.08 \pm 1.30$ & $\mathrm{NS}$ & - \\
$\mathrm{pH}$ & $5.00-6.00$ & $5.83 \pm 0.09$ & $6.5-8.5$ & $7.0-8.5$ \\
Alkalinity $(\mathrm{mg} / \mathrm{L})$ & $36.00-132.00$ & $84.78 \pm 6.38$ & $\mathrm{NS}$ & - \\
Conductivity $(\mu \mathrm{S} / \mathrm{cm})$ & $9.00-37.00$ & $23.39 \pm 2.58$ & $\mathrm{NS}$ & $\leq 1,000$ \\
Ammonia $(\mathrm{mg} / \mathrm{L})$ & $0.32-0.91$ & $0.63 \pm 0.04$ & $<0.1$ & $<0.1$ \\
Total Dissolved Solid $(\mathrm{mg} / \mathrm{L})$ & $5.00-12.00$ & $7.56 \pm 0.49$ & $\mathrm{NS}$ & $\leq 200.0$ \\
Total Suspended Solid (mg/L) & $1.39-7.14$ & $3.84 \pm 0.51$ & 0.25 & $\leq 5.0$ \\
Nitrate-Nitrogen (mg/L) & $0.05-0.05$ & $0.05 \pm 0.00$ & 9.1 & $\geq 10.0$ \\
Dissolved Oxygen(mg/L) & $4.60-10.00$ & $6.51 \pm 0.33$ & $\mathrm{Not}<6.0$ & $\geq 5.0$ \\
Hardness (mg/L) & $52.00-156.00$ & $105.24 \pm 6.63$ & $\mathrm{NS}$ & - \\
Carbon IV Oxide (mg/L) & $6.00-32.00$ & $17.56 \pm 1.82$ & $<20.0$ & - \\
Chloride (mg/L) & $32.00-108.00$ & $68.50 \pm 4.06$ & 300 & - \\
\hline
\end{tabular}

$\mathrm{SE}=$ standard error of mean, NS=Not Specified, and $\mathrm{a}={ }^{\mathrm{a}}$ except in mixing zones, temperature increase by a 7-Day Average of the Daily Maximum temperatures (7-DADMax) shall not be more than $0.3^{\circ} \mathrm{C}$ above natural background conditions

Table 2 Spatial variation in Physico-chemical parameters of Oguta Lake between July and September, $(P<0.05)$

\begin{tabular}{|c|c|c|c|}
\hline \multirow{2}{*}{ Parameters } & \multicolumn{3}{|c|}{ Stations } \\
\hline & I & 2 & 3 \\
\hline Temperature $\left({ }^{\circ} \mathrm{C}\right)$ & $28.08^{a}$ & $27.92^{\mathrm{a}}$ & $28.00^{\mathrm{a}}$ \\
\hline Transparency (m) & $1.29^{\mathrm{a}}$ & $1.07^{\mathrm{a}}$ & $1.10^{\mathrm{a}}$ \\
\hline Current (m/s) & $10.88^{a}$ & $12.25^{\mathrm{a}}$ & $13.12^{\mathrm{a}}$ \\
\hline $\mathrm{Ph}$ & $6.00^{\mathrm{a}}$ & $5.83^{\mathrm{a}}$ & $5.67^{\mathrm{a}}$ \\
\hline Alkalinity (mg/L) & $99.33^{\mathrm{a}}$ & $81.33^{\mathrm{a}}$ & $73.67^{\mathrm{a}}$ \\
\hline Conductivity & $25.33^{\mathrm{a}}$ & $18.50^{\mathrm{a}}$ & $26.33^{\mathrm{a}}$ \\
\hline Ammonia (mg/L) & $0.65^{\mathrm{ab}}$ & $0.5 \mathrm{Ib}$ & $0.73^{\mathrm{a}}$ \\
\hline Total Dissolved Solid (mg/L) & $6.83^{\mathrm{a}}$ & $7.17^{\mathrm{a}}$ & $8.67^{\mathrm{a}}$ \\
\hline Total Suspended Solid (mg/L) & $3.03^{\mathrm{a}}$ & $3.14^{\mathrm{a}}$ & $5.35^{\mathrm{a}}$ \\
\hline Nitrate-Nitrogen (mg/L) & $0.05^{\mathrm{a}}$ & $0.05^{\mathrm{a}}$ & $0.05^{\mathrm{a}}$ \\
\hline Dissolved Oxygen (mg/L) & $6.55^{\mathrm{ab}}$ & $7.57^{\mathrm{a}}$ & $5.40^{\mathrm{b}}$ \\
\hline Hardness (mg/L) & $105.40^{\mathrm{a}}$ & $109.67^{a}$ & $100.67^{\mathrm{a}}$ \\
\hline Carbon IV Oxide (mg/L) & $18.00^{\mathrm{a}}$ & $14.83^{\mathrm{a}}$ & $19.83^{\mathrm{a}}$ \\
\hline Chloride (mg/L) & $68.00^{\mathrm{a}}$ & $74.00^{\mathrm{a}}$ & $63.50^{\mathrm{a}}$ \\
\hline
\end{tabular}

N.B: Values with the same superscript along same row are not significantly different at $\mathrm{P}<0.05$ 
Table 3 Checklist of Benthic Macro-invertebrates taxa in Oguta Lake, Between July and September 20I9

\begin{tabular}{|c|c|c|c|}
\hline Phylum & Class & Order & Species \\
\hline \multirow[t]{2}{*}{ Mollusca } & Gastropoda & Sorbeoconcha & Melanoides tuberculata $* * *$ \\
\hline & & Basommatophora & Gabiella africana**** \\
\hline \multirow[t]{8}{*}{ Arthropoda } & Insecta & Diptera & Chironomus sp*** \\
\hline & & & Cranefly larvae** \\
\hline & & Ephemeroptera & Mayfly nymph* \\
\hline & & Odonata & Dragongfly** \\
\hline & & & Sympterum sp** \\
\hline & & Coleoptera & Helophorus species* \\
\hline & & & Riffle beetle adult* \\
\hline & & Plecoptera & Atoperla sp* \\
\hline
\end{tabular}

$*=$ Sensitive/ Intolerant species, $* *=$ Moderately Intolerant species, $* * *=$ Fairly tolerant species, $* * * *=V e r y$ tolerant species

Table 4 Relative Abundance of Macro-invertebrates taxa in Oguta Lake Between July and September 2019

\begin{tabular}{|c|c|c|c|c|c|c|}
\hline \multirow[t]{2}{*}{ Class/order } & \multirow[t]{2}{*}{ Species } & \multicolumn{3}{|c|}{ Abundance } & \multirow{2}{*}{ Total abundance } & \multirow{2}{*}{$\begin{array}{l}\text { Percentage } \\
\text { abundance (\%) }\end{array}$} \\
\hline & & July & August & September & & \\
\hline \multirow[t]{2}{*}{ GASTROPODA } & Melanoidestuberculata & - & I & - & $\mathrm{I}$ & 0.7 \\
\hline & Gabiellaafricana & 2 & - & - & 2 & 1.5 \\
\hline Total & & 2 & 1 & - & 3 & 2.2 \\
\hline \multirow[t]{8}{*}{ INSECTA- } & Chironomussp & 10 & 19 & 18 & 47 & 34.3 \\
\hline & Cranefly larvae & - & 2 & - & 2 & 1.5 \\
\hline & Mayfly nymph & 10 & 16 & 13 & 39 & 28.5 \\
\hline & Drangonfly nymph & 8 & 10 & 6 & 24 & 17.5 \\
\hline & Sympetrumsp & - & I & - & I & 0.7 \\
\hline & Helophorus sp & 2 & 2 & - & 4 & 2.9 \\
\hline & Riffle beetle adult & 4 & 8 & 4 & 16 & 11.7 \\
\hline & Atoperla sp & $\mathrm{I}$ & - & - & I & 0.7 \\
\hline Total & & 35 & 58 & 41 & 134 & 97.8 \\
\hline Grand Total & & 37 & 59 & $4 I$ & 137 & 100 \\
\hline
\end{tabular}

Table 5 Diversity index of Benthic Macro-invertebrates in Oguta Lake during the study period

\begin{tabular}{llll}
\hline Taxa & H & D & E \\
\hline Chironomus sp & $2.344^{*}$ & 2.873 & 0.869 \\
Mayfly nymph & 2.284 & 0.919 & $0.818^{*}$ \\
Drangonfly nymph & $\mathrm{I} .676$ & $\mathrm{I} .573$ & $0.89 \mathrm{I}$ \\
Gabiellaafricana & 0.693 & $\mathrm{I} .443$ & $\mathrm{I}$ \\
Riffle beetle adult & $\mathrm{I} .32 \mathrm{I}$ & $\mathrm{I} .082$ & 0.937 \\
mean \pm SE & 0.832 & 0.789 & 0.952 \\
\hline
\end{tabular}

$\mathrm{H}=$ Shanon-Wiener's index, $\mathrm{D}=$ Margalef index, and $\mathrm{E}=$ Evenness 


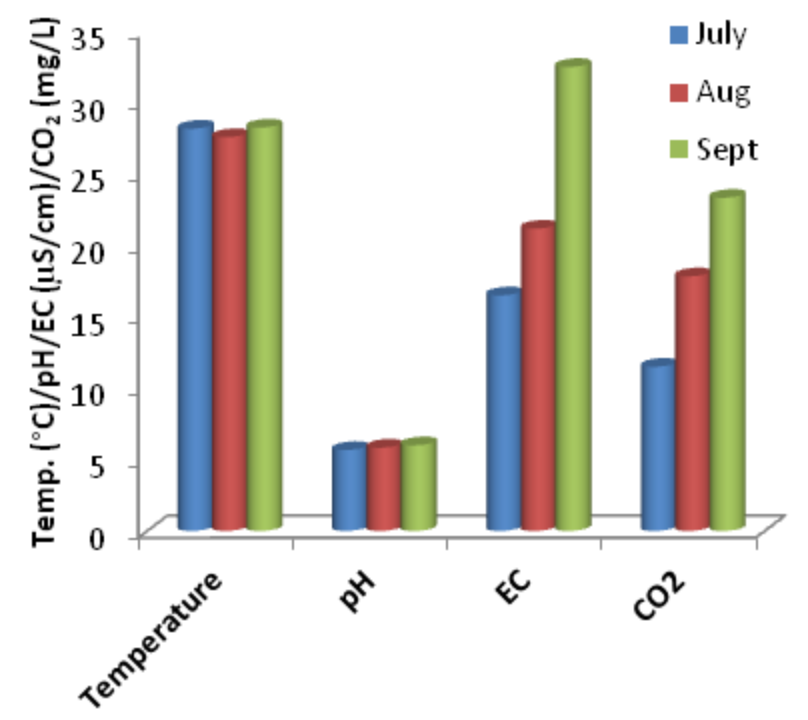

Figure 2 Temporal variations in mean water temperature, $\mathrm{pH}$, Electrical conductivity and Dissolved $\mathrm{CO}_{2}$ in the Oguta Lake.

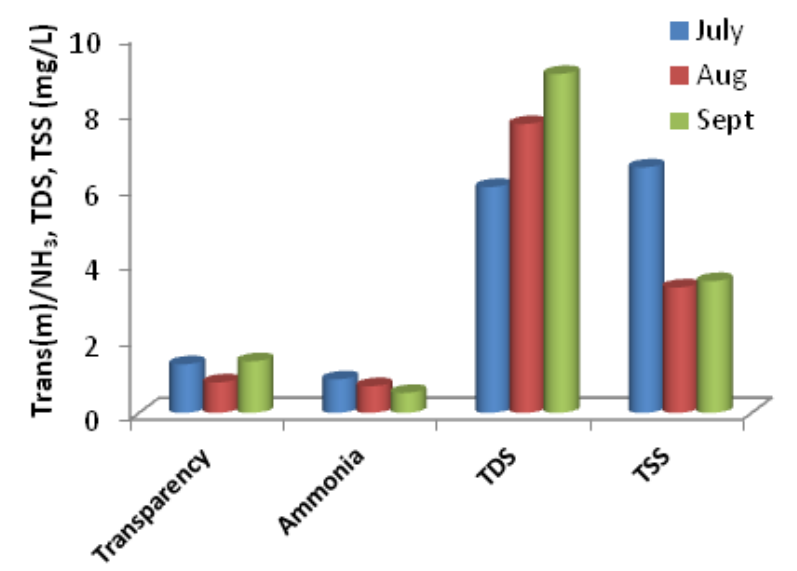

Figure 3 Temporal variations in mean Transparency,Ammonia, Total dissolved and suspended solids in the Oguta Lake.

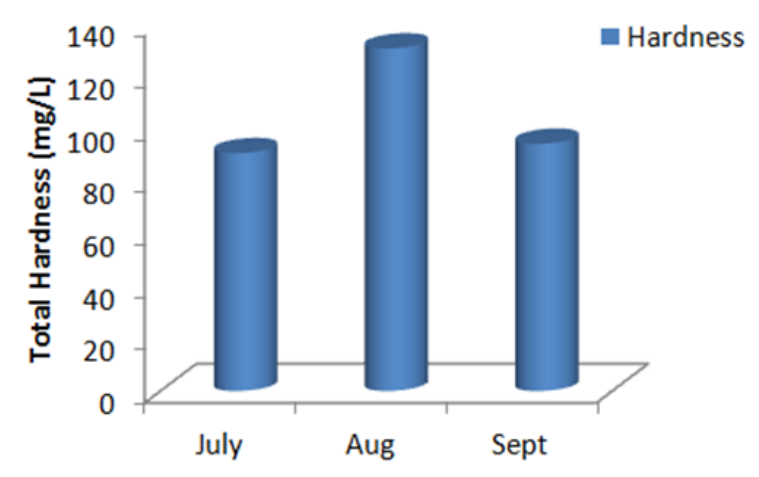

Figure 4 Temporal variations in mean Total Hardness in the Oguta Lake.

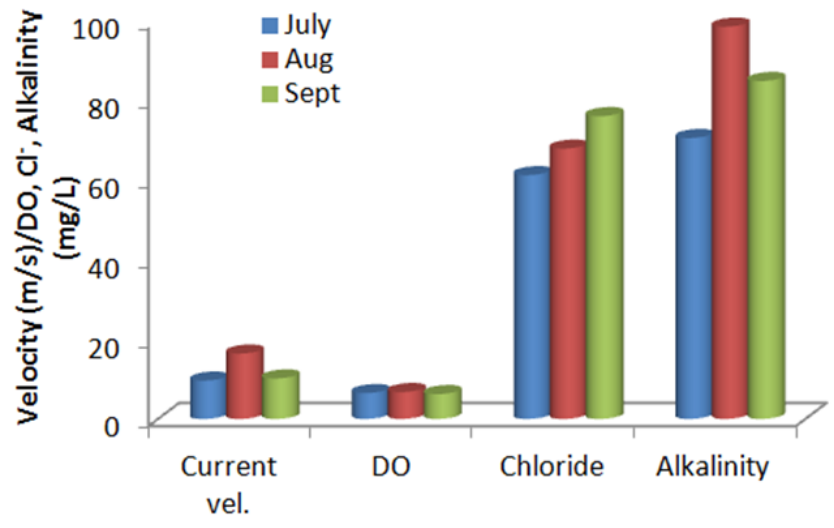

Figure 5 Temporal variations in mean current velocity, Dissolved oxygen, Chloride ions and Total alkalinity of the Oguta Lake.

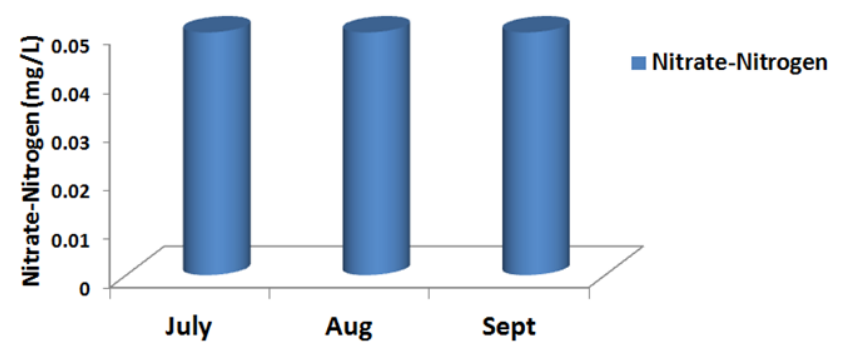

Figure 6 Temporal variations in mean Nitrate-Nitroge in the Oguta Lake.

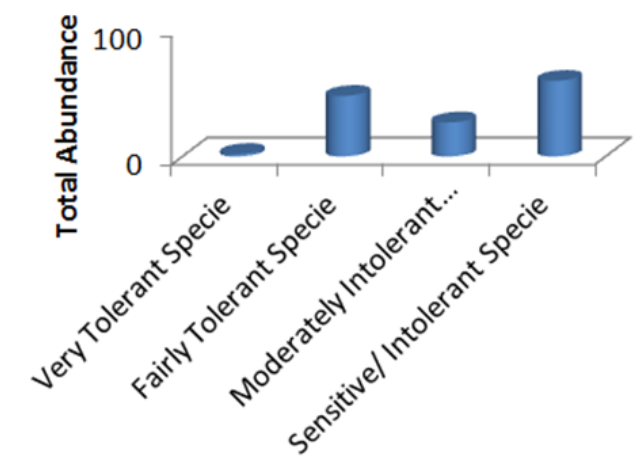

Figure 7 Variations in the indicator species of the Macro-invertebratess of Oguta Lake during the study period.

\section{Macro-invertebrates diversity index}

The results of the Macro-invertebrates diversity analysis are presented in Table 6 accordingly. Shannon-Weiner's index (H) revealed Chironomus sp was observed to record higher diversity index (2.34) while Mayfly nymph was least evenly distributed (0.818). The spatial diversity indices for the Macro-invertebrates fauna recorded in the three sampling stations during the study period are presented in. Sampling station 2 recorded the highest diversity index $(\mathrm{H}=0.768)$ while station 1 recorded the least diversity index $(\mathrm{H}=0.399)$. Sampling 
station 2 recorded the overall highest percentage abundance $(77 \%)$, while station 1 recorded the least abundance $(15 \%)$. The general order of abundance of Macro- invertebrates across the sampling stations were $2>1>3$ (Figure 8 ).

Table 6 Spatial Diversity indices of Benthic Macro-invertebrates in Oguta Lake during the study period

\begin{tabular}{|c|c|c|c|c|c|c|c|c|c|}
\hline \multirow[t]{2}{*}{ TAXA } & \multicolumn{3}{|c|}{ Station I } & \multicolumn{3}{|c|}{ Station 2} & \multicolumn{3}{|c|}{ Station 3} \\
\hline & $\mathbf{H}$ & D & $\mathbf{E}$ & $\mathbf{H}$ & D & $\mathbf{E}$ & $\mathbf{H}$ & D & $\mathbf{E}$ \\
\hline Chironomussp & 0.9 & 0.961 & 0.82 & 1.706 & 1.47 & 0.918 & 1.082 & 0.962 & 0.984 \\
\hline Mayfly nymph & 1.224 & 1.038 & 0.85 & 1.514 & 1.412 & 0.909 & 1.04 & 1.443 & 0.943 \\
\hline Drangonfly nymph & 0 & 0 & I & 1.516 & 1.294 & 0.911 & - & - & - \\
\hline Gabiellaafricana & 0 & 0 & I & - & - & - & 0 & 0 & I \\
\hline Riffle beetle adult & 0.673 & 0.434 & 0.98 & 0.637 & 0.558 & 0.945 & - & - & - \\
\hline Mean & 0.399 & 0.348 & 0.95 & 0.768 & 0.676 & 0.955 & 0.707 & 0.802 & 0.976 \\
\hline
\end{tabular}

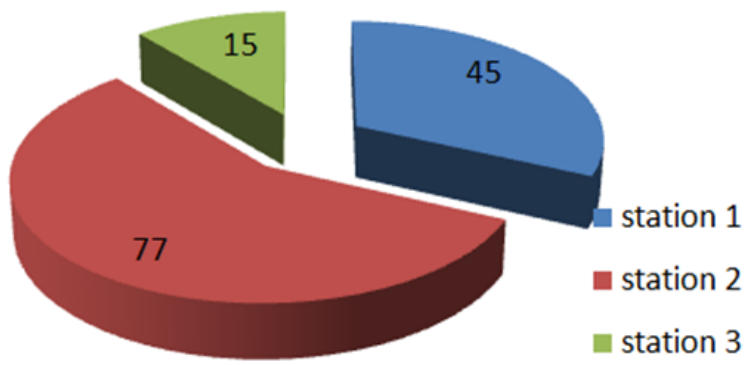

Figure 8 Spatial variation in macro- invertebrate composition and abundance.

\section{Discussion and conclusion}

Temperature is an important factor that influences primary production in lakes and it depends on the climate, sun light and depth. ${ }^{17,18}$ Aquatic organisms (from microorganisms to fish) depend on certain temperature range for optimal growth. ${ }^{14}$ The mean water temperature of $28.00^{\circ} \mathrm{C} \pm 0.20$ recorded in the present study falls within the water temperature in the tropics and the recommended limit for optimum fish growth, as earlier observed by Mustapha, ${ }^{19}$ and Usman. ${ }^{20}$ The observed gradation in Oguta Lake surface water temperature is comparable to that of other fresh water bodies in Nigeria; Adebayo \& Ayoade $^{9}$ in Itapaji Reservoir, Edward and Ugwumba ${ }^{21}$ in Egbe Dam, where lower temperature during heavy rains is due to the influx of cooler freshwater and heavy cold cloud covers. Higher surface water temperature of the lake at the onset of the rainy season could be attributed to the solar radiation (insulation) and the reduced water depths a result of reduction in inflow.

The recorded variations in mean transparency values of Oguta Lake could be attributed to high water run-off into the lake. This probably washed silts, sediments, debris, organic, inorganic and suspended particles into the water body, enhancing the total suspended solid of the lake; subsequently the light attenuation by the particles reduced the Secchi disc visibility that makes the water turbid. Similar observation was reported by Adebayo et al, ${ }^{22}$ Adebayo \& Ayoade, ${ }^{9}$ Mustapha, ${ }^{19}$ Mustapha. ${ }^{23}$ The authors opined that increased concentration of this parameters decreased light penetration into the water. Though turbidity is not necessarily harmful to fish, the resulting reduction of sunlight intensity in the water column decreases the primary productivity of water body thus, impacting negatively on the entire ecological trophic chains. Additionally, pollutants in turbid waters could be injurious to organisms once they gain entry into their bodies.

Low level of total dissolved solids could be probably due to higher activities of aerobic bacteria causing degradations of the eroded organic particles into the lake. . This was further proven in the recorded excess load of total suspended solid of the lake. ${ }^{24}$ The evidence could also be further confirmed as the station 1 has the least value of DO and it received the highest waste from the major tributaries of the lake. This has tendency of reducing the light penetration into the reservoir which may lead to a reduced photosynthesis and in turn reduce dissolved oxygen of the lake, with consequent effects on both phytoplankton and zooplankton populations of the aquatic environment. The recorded peak value in the TSS of the lake established that the solids originated from the erosion and runoff of the adjourning land. These factors combined could be responsible to the recorded low taxa and number of Macro-invertebratess fauna of the lake.

Habitat destruction due to settling of the recorded high total suspended solid might have influenced the overall composition and abundance of the benthic fauna of the Lake. These factors probably caused disruption of life cycle, reproductive cycle, food chain and migrations or imposed physiological stress on even the tolerant benthic Macro-invertebratess. This observation is not unusual with some earlier report ${ }^{22,25,26}$ in tropical waters. Furthermore, another factor that might be responsible for the recorded low taxa of benthos in the lake might be predators such as fish that exploit invertebrate. The highest diversity index in Chironomus sp could be as a result of their ability to utilize more oxygen due to their possession of the oxygen binder pigment- Haemin in their red blood cell. Conclusively, owing to the overall mean diversity index of 0.832 , oguta Lage is unstable, ${ }^{27-29}$ this could be linked to the resultant effects of the various organic 
and inorganic wastes discharge ranging from municipal waste such as sewage waste, to household waste, and agricultural field run- offs into Oguta Lake that had influenced it physico- chemical parameters, and the diversity of macro- invertebrates. Thus concise efforts should be made by Government to restrict the populace on using water and water ways as their major mean of discharging wastes. ${ }^{30,31}$

\section{Acknowledgments}

None.

\section{Conflicts of interest}

The authors declares that there is no conflict of interest.

\section{Funding}

None.

\section{References}

1. Kigbu AA, Mohammed US. Physico - chemical Parameters and fish abundance of River Amba in Lafia, Nasarawa state, Nigeria. Journal of Aquatic science. 2013;272-273.

2. Ogbogu SS, Olajide SA. Effect of sewage oxidation pond effluent on Macroinvertebrate communities of a tropical forest stream, Nigeria. Journal of Aquactic science. 2002;17(1):22-27.

3. Ogbeibu AE, Ezerunara PU. Ecological impact of brewery effluent on the Ikpoba river using the fish communities as bioindicators. J Aqu Sci. 2002;17(1):35-44.

4. Nwankwo DI. The influence of sawmill wood wastes on diatom population at Okobaba, Lagos, Nigeria. Chem Biodivers. 2006;3(5):578592.

5. Barbour MT, Gerritsen J, Synder BD, et al. Rapid bio- assessment protocols for use in streams and Rivers Periphyton, benthic macroinvertebrates and fish. $2^{\text {nd }}$ Edition. EPA 841-B-99-002. US Environmental Protection agency. Office of water. Washington, DC, USA. 1999;339.

6. Banada N, Prat N, Resh VH, et al. Developments in aquatic insect bio monitoring: A Comparative analysis of recent approaches. Annual Review of Entomology. 2006;51:495-523.

7. Omni VR. The diversity and abundance of phytoplankton of Oguta Lake. BSc. Thesis. University of portharcourt, Port- Harcourt, Nig. 1983.

8. Ogidi MI, Nwadiaro CS. Geophysical limnology of Oguta Lake in southeastern Nigeria with notes on its possible origin. Aquatic ecology. 1988;22(2):113-126.

9. Adebayo ET, Ayoade AAA. Assessment of Physico-chemical Parameters of Itapaji Reservoir, Itapaji, South-western Nigeria. Ethiopian Journal of Environmental Studies and Management. 2017;10(10):1284-1297.

10. Ogueri C, Adebayo ET, Nwaiwu VNC. Assessment of heavy metals in fish species and some physico-chemical parameters of Oguta Lake, Oguta, Imo State, Nigeria. International Journal of Hydrology. 2018;2(2):116-119.

11. Nfor BN, Akaegbobi IM. Inventory of the Quaternary Geology and the Evolution of the Oguta Lake, in Southeastern Nigeria. World Journal of Engineering and Pure and Applied Sci. 2012;2(1):249-0582.

12. Boyd CE. Determination of Total Ammonia Nitrogen and Chemical Oxygen Demand in Fish culture system. Transactions of American Fisheries Society. 1979;108(3):314-319.

13. Mackerecth. Method of water analysis for Limnologist Fresh water bio. Ass scient publ. 1979;21-71.
14. American Public Health Association- APHA. Standard Methods for the Examination of Water and Wastewater. $20^{\text {th }}$ edition. APHA/AWWA/ WEF: Washington DC. USA. 1998. p. 1213.

15. APHA/AWWA/WEF. Standard methods for the examination of water and waste water $19^{\text {th }}$ edition. American Public Health Association Inc., Washington, D.C. 1992. 4800p.

16. Hawking JH. A preliminary guide to keys and zoological information to identify invertebrates from Australian inland water $2^{\text {nd }}$ Edition Murray Darling freshwater research Public Australia no 2. 2010. p. 71.

17. Lewis MW. Basis for the protection and management of tropical lakes. Lakes Reserve Management. 2000;5:35-48.

18. Abolude DS. Water quality and metal concentrations in sediments and fish from Ahmadu Bello University Reservoir, Zaria, Nigeria. Ph.D Thesis Ahmadu Bello University, Zaria. 2017. p. 226.

19. Mustapha MK. Phytoplankton assemblage of a small, shallow, tropical African reservoir. International ournal of Tropical Biology. 2009;57(4):1009-1025.

20. Usman H. Determination of physico-chemical parameters and plankton composition of Wawan-rafi Lake in Kazaure, Nigeria. M. Sc Dissertation, Ahmadu Bello University, Zaria. 2013. p. 76.

21. Edward JB, Ugwumba AAA. Physico-chemical parameters and plankton community of Egbe Reservoir, Ekiti State, Nigeria. Research Journal of Biological Sciences. 2010;5(5):356-367.

22. Adebayo ET, Ayoade AAA, Ekeledo CB. Bio-assessment of ecological health Status of Itapaji Reservoir, Itapaji, South-western Nigeria. Elixir aquaculture. 2019;135(2019):53758-53762.

23. Mustapha MK. Effects of human activities on the biodiversity of a tropical man-made lake. Nigerian Journal of Pure and Applied Sciences. 2006;21:1960-1968.

24. National Environmental Standards and Regulations Enforcement Agency (NESREA). National environmental (surface and groundwater quality control) regulations. Federal Republic of Nigeria Official Gazette. 2011;98.

25. Adakole JA, Annune PA. Benthic macro-invertebrate as indicators of Environmental Quality of an Urban Stream, Zaria, Northern Nigeria. Journal of Aquatic Science. 2003;18(2):85-92.

26. Tamuno PBL. Eco-livelihood assessment of inland river dredging. the Kolo and Otuoke creeks, Nigeria, a case study. Ph.D. Thesis, Loughbourogh University. 2005. p. 351.

27. Shannon C. A mathematical theory of communication. Bell Systems Technology Journal. 1948;27:379-423.

28. Lenat DR, Smock LA, Penrose DL. Use of benthic Macro-invertebratess as indicators of environmental quality. In: Douglass LW, Editors. Biological monitoring for environmental effects. Toronto: Lexington Books. 1980;97-114.

29. Mandaville SM. Benthic Macro-invertebratess in Freshwater - taxa tolerance values, metrics, and protocols, project H - 1. Nova Scotia: Soil \& Water Conservation Society of Metro Halifax. 2002.

30. Adebayo ET, C-Oluwatosin TJ, Nneji PC. Limnological assessment of heavy metals concentration in water and sediment of Oguta Lake, South-eastern Nigeria, Nigeria. International Journal of Innovative Studies in Aquatic Biology and Fisheries (IJISABF). 2017;3(3):18-22.

31. World Health Organization -WHO. Guidelines for drinking water quality. $3^{\text {rd }}$ Edition. Health Criteria and Supporting Information, Geneva. 2008. 